\title{
Renal dysfunction in patients with sickle cell anemia or sickle cell trait
}

\section{R. Sesso ${ }^{1}$, M.A. Almeida ${ }^{1}$, M.S. Figueiredo ${ }^{2}$ and J.O. Bordin²}

Divisões de ${ }^{1} \mathrm{~N}$ efrologia e ${ }^{2} \mathrm{H}$ ematologia, Escola Paulista de Medicina, Universidade Federal de São Paulo, São Paulo, SP, Brasil

\section{Correspondence \\ R. Sesso \\ Divisão de Nefrologia \\ EPM, UNIFESP \\ Rua Botucatu, 740 \\ 04023-900 São Paulo, SP \\ Brasil \\ Fax: + 55-11-573-9652 \\ E-mail: rsesso@ nefro.epm.br \\ Research supported by CNPq. Publication supported by FAPESP}

Received March 5, 1998

Accepted July 28, 1998

\section{Abstract}

Patients with sickle cell anemia (Hb SS) or sickle cell trait (Hb AS) may present several types of renal dysfunction; however, comparison of the prevalence of these abnormalities between these two groups and correlation with the duration of disease in a large number of patients have not been thoroughly investigated. In a cross-sectional study using immunoenzymometric assays to measure tubular proteinuria, microalbuminuria, measurement of creatinine clearance, urinary osmolality and analysis of urine sediment, we evaluated glomerular and tubular renal function in 106 adults and children with $\mathrm{Hb} \mathrm{SS}(\mathrm{N}=66)$ or $\mathrm{Hb}$ AS $(\mathrm{N}=40)$ with no renal failure (glomerular filtration rate $(\mathrm{GFR})>85$ $\mathrm{ml} / \mathrm{min}$ ). The percentage of individuals with microalbuminuria was higher among $\mathrm{Hb} \mathrm{SS}$ than among $\mathrm{Hb}$ AS patients ( 30 vs 8\%, $\mathrm{P}<0.0001)$. The prevalence of microhematuria was similar in both groups (26vs $30 \%$, respectively). Increased urinary levels of retinol-binding protein or $\beta_{2}$-microglobulin were detected in only $3 \mathrm{Hb} \mathrm{SS}$ and $2 \mathrm{Hb} \mathrm{AS}$ patients. Urinary osmolality was reduced in patients with $\mathrm{Hb}$ SS or with $\mathrm{Hb} \mathrm{AS}$; however, it was particularly evident in $\mathrm{Hb} \mathrm{SS}$ patients older than 15 years $($ median $=393 \mathrm{mOsm} / \mathrm{kg}$, range $=366-469)$ compared with $\mathrm{Hb}$ AS patients (median $=541 \mathrm{mOsm} / \mathrm{kg}$, range $=406$ 722). Thus, in addition to the frequently reported early reduction of urinary osmolality and increased GFR, nondysmorphic hematuria was found in 26 and $30 \%$ of patients with $\mathrm{Hb}$ SS or $\mathrm{Hb} \mathrm{AS}$, respectively. Microalbuminuria is an important marker of glomerular injury in patients with $\mathrm{Hb}$ SS and may also be demonstrated in some $\mathrm{Hb}$ AS individuals. Significant proximal tubular dysfunction is not a common feature in $\mathrm{Hb} \mathrm{SS}$ and $\mathrm{Hb}$ AS population at this stage of the disease (i.e., GFR $>85 \mathrm{ml} / \mathrm{min}$ ).

\section{Introduction}

The kidney of the homozygous sickle cell anemia $(\mathrm{Hb} \mathrm{SS})$ patient is affected by the hemodynamic changes of chronic anemia and by the consequences of vaso-occlusion, especially in the renal medulla $(1,2)$. The disruption of distal nephron and medullary function leads to a reduction of renal concen-
Key words

- Microalbuminuria

- Renal failure

- Renal function

- Sickle cell disease 
lar changes. The contribution of the deteriorating glomerular function to morbidity and mortality in older patients has not been widely recognized $(5,6)$. Proteinuria has been described alone or in association with renal vein thrombosis, hematuria, leg ulcers, acute or chronic glomerulonephritis, and the other components of the nephrotic syndrome (6). The prevalence rate of proteinuria in patients with $\mathrm{Hb} \mathrm{SS}$ has been reported to vary from 17 to $33 \%$ in studies in which proteinuria was determined by the dipstick method (7). While asymptomatic and relatively common, proteinuria seems to be associated with reduced creatinine clearance in $\mathrm{Hb} \mathrm{SS}$ patients older than 40 years.

In the present study we determined the prevalence of early glomerular and proximal tubular dysfunction in individuals with either $\mathrm{Hb}$ SS or sickle cell trait (Hb AS). In addition, the possible correlation between renal dysfunction and duration of disease was investigated.

\section{Subjects and Methods}

A cross-sectional study was conducted on 106 individuals, 66 patients with documented $\mathrm{Hb}$ SS (median age: 22 years ( 2 to 49 years)) and 40 individuals with $\mathrm{Hb}$ AS (median age: 28 years (5 to 69 years)). All subjects were followed at the Hematology Service of Escola Paulista de Medicina and Faculdade de Ciências Médicas da Santa Casa de Misericórdia, São Paulo, SP, Brazil. The exclusion criteria were: documented acute or chronic infection, painful crisis, or hemodynamic instability. The presence of infection was assessed by medical history, clinical examination and, when indicated, laboratory tests such as complete blood count, urinalysis (urine cultures were usually done if there was leucocyturia $>10,000$ cells $/ \mathrm{mm}^{3}$ ), blood cultures, chest $\mathrm{X}$ ray, abdominal ultrasonography, etc. The diagnosis of Hb SS or $\mathrm{Hb} \mathrm{AS}$ was based on clinical features, family history, and laboratory investigation. Labo- ratory techniques included hemoglobin electrophoresis on cellulose acetate, $\mathrm{pH} 8.9$, and on agar gel, pH 6.2 (8), the solubility test (9), and the estimation of both $\mathrm{Hb} \mathrm{F}(10)$ and $\mathrm{Hb} \mathrm{A}_{2}$ (8). The individuals with $\mathrm{Hb}$ AS were either parents or siblings of the patients with $\mathrm{Hb}$ SS included in the study.

Total protein in urine was measured by the biuret method (11) and the level of serum creatinine was determined by the Jaffé reaction (12). Creatinine clearance determinations were based on 24-h urine collection and were calculated as follows: (urine creatinine x 24-h urine volume)/plasma creatinine. Patients were carefully instructed on how to collect urine at home and bring it to the laboratory at the end of the procedure. All creatinine clearance results were adjusted for body surface area $\left(1.73 \mathrm{~m}^{2}\right)$. The level of $\beta_{2}$-microglobulin in serum or urine was determined using a commercially available kit (Enzygnost $\beta_{2}$-microglobulin, Behring Institute, Mannheim, Germany, upper normal limit $=200 \mu \mathrm{g} / \mathrm{l})$. A monoclonal antibodybased immunoenzymometric assay was used to determine urinary retinol-binding protein $(\mathrm{RBP}$, upper normal limit $=400 \mu \mathrm{g} / \mathrm{l})(13)$. Microalbuminuria was quantitated by ELISA (upper normal limit $=20 \mathrm{mg} / \mathrm{l}$ ). Urinary osmolality was measured by the freezing point depression method using a $3 \mathrm{~W} 2$ osmometer (Advanced Instruments Inc., Needham Heights, MA). $\beta_{2}$-Microglobulin, RBP, microalbuminuria and urinary osmolality (after 12-16 $\mathrm{h}$ dehydration) were determined in urine samples. Previous studies from our institution have shown an excellent correlation between urinary RBP (or $\beta_{2}$-microglobulin) expressed as $\mu \mathrm{g} / \mathrm{l}$ and the respective values corrected for urinary creatinine, when renal function is preserved, as was the case for the present patients (13). We preferred to express the results of these parameters as $\mu \mathrm{g} /$ 1. Hematuria was defined as the presence of 8 or more red blood cells per high power microscopic field in the urine sediment. If there was hematuria, an evaluation of eryth- 
rocyte morphology was carried out using phase contrast microscopy.

\section{Statistical analyses}

Statistical analyses were performed using nonparametric methods. The MannWhitney test was used for the comparison of continuous variables, while the chi-square test was used for the comparison of categorical variables, with the level of significance set at 0.05 (two-tailed).

\section{Results}

Table 1 summarizes the laboratory results obtained for the two groups of individuals. $\mathrm{Hb}$ SS patients had a significantly lower level of serum creatinine and urinary osmolality than $\mathrm{Hb}$ AS individuals. In contrast, patients with $\mathrm{Hb}$ SS showed a significantly higher level of creatinine clearance, microalbuminuria, and serum $\beta_{2}$-microglobu- lin than individuals with $\mathrm{Hb} \mathrm{AS}$.

The percentage of individuals with microalbuminuria was significantly higher in $\mathrm{Hb}$ SS than $\mathrm{Hb}$ AS patients (30 vs 8\%, $\mathrm{P}<0.0001)$. However, the presence of hematuria was quite similar in both groups (26 vs $30 \%)$. In the group of patients with $\mathrm{Hb}$ AS we detected one patient showing gross hematuria and another having dysmorphic erythrocytes in the urine.

Seven patients with $\mathrm{Hb} \mathrm{SS}$ and 2 patients with $\mathrm{Hb}$ AS showed a 24-h total proteinuria level of 0.2 to $1.0 \mathrm{~g}$, whereas one $\mathrm{Hb} \mathrm{SS}$ patient presented 24-h proteinuria of $1.65 \mathrm{~g}$. None of these patients showed clinical evidence of nephrotic syndrome (edema). Increased values of urinary RBP and $\beta_{2}$-microglobulin were detected in 1 and 3 patients with $\mathrm{Hb} \mathrm{SS}$, respectively. Two individuals with $\mathrm{Hb}$ AS had increased levels of $\beta_{2}$-microglobulin, but none had elevated urinary RBP.

The results of the laboratory parameters

\begin{tabular}{|c|c|c|c|}
\hline Parameter & $\mathrm{Hb}$ AS & $\mathrm{Hb}$ SS & P Value \\
\hline Number of patients & 40 & 66 & - \\
\hline Median age (range) (years) & $28(5-69)$ & $22(2-49)$ & ns \\
\hline Female/male ratio & $32 / 8$ & $40 / 26$ & - \\
\hline Serum creatinine $(\mathrm{mg} / \mathrm{dl})$ & $0.70(0.4-1.1)$ & $0.60(0.3-1.3)$ & $<0.01$ \\
\hline Creatinine clearance $\left(\mathrm{ml} / \mathrm{min} / 1.73 \mathrm{~m}^{2}\right)$ & $108(86-212)$ & $118(87-229)$ & $<0.01$ \\
\hline Urinary osmolality $(\mathrm{mOsm} / \mathrm{kg})$ & $567(333-829)$ & $399(271-580)$ & $<0.001$ \\
\hline Microalbuminuria (mg/l) & $6.8(0.8-364.0)$ & $10.5(0.7-2022.0)$ & $<0.05$ \\
\hline Number of patients with higher than normal values (\%) & $3 / 39(8)$ & 19/64 (30) & $<0.0001$ \\
\hline Hematuria (cells/field, 400X) & $3(0-80)$ & $3(0-15)$ & ns \\
\hline Number of patients with higher than normal values* (\%) & $12 / 40(30)$ & $17 / 66(26)$ & ns \\
\hline Urinary RBP $(\mu g / l)$ & $35(5-261)$ & $45(7-462)$ & ns \\
\hline Number of patients with higher than normal values (\%) & $0 / 34(0)$ & $1 / 49(2)$ & ns \\
\hline Urinary $ß_{2}$-microglobulin $(\mu \mathrm{g} / \mathrm{l})$ & $55(12-224)$ & $72(15-761)$ & ns \\
\hline Number of patients with higher than normal values (\%) & $2 / 40(5)$ & $3 / 64(5)$ & ns \\
\hline Serum $ß_{2}$-microglobulin (mg/l) & $1.39(0.58-2.59)$ & $1.92(0.82-3.65)$ & $<0.0001$ \\
\hline
\end{tabular}


according to age group for the two groups of individuals are shown in Table 2. In the $\mathrm{Hb}$ SS group, patients older than 15 years showed a significantly higher level of serum creatinine and microalbuminuria excretion compared to the group of $\mathrm{Hb}$ SS patients under 15 years of age. However, Hb SS patients over 15 years of age showed a significantly lower urinary osmolality than $\mathrm{Hb}$ SS patients under 15 years. All 19 (49\%) Hb SS patients with microalbuminuria were over 15 years of age (Figure 1).

In $\mathrm{Hb} \mathrm{SS}$ patients, the median (range) $\mathrm{Hb}$ $F$ value was similar for subjects with or without microalbuminuria, i.e., $5.1 \%$ (1.88.4) vs 5.3\% (0.3-20.3), respectively. In these subgroups (with or without microalbuminuria), median (range) creatinine clearance was also not significantly different, i.e., $133 \mathrm{ml} /$ $\min (96-169)$ vs $118 \mathrm{ml} / \mathrm{min} / 1.73 \mathrm{~m}^{2}$ (87192), respectively.

Urinary osmolality was reduced in both patients with $\mathrm{HbSS}$ and with $\mathrm{Hb} \mathrm{AS}$, but this reduction was particularly evident in $\mathrm{Hb} \mathrm{SS}$ patients over 15 years of age.

\section{Discussion}

In the present study we evaluated the renal function of a relatively large number of adults and children with either $\mathrm{Hb} \mathrm{SS}$ or $\mathrm{Hb}$ AS. It has been reported that patients with Hb SS may present several types of renal dysfunction including hyposthenuria, hematuria, proteinuria, nephrotic syndrome, acidosis, urinary tract infection, renal failure, and changes in arterial blood pressure (6). The inability to concentrate urine appropriately has been the most consistent feature of sickle cell nephropathy which has been reported to occur in all sickle cell disorders, including $\mathrm{Hb} \mathrm{AS}(6,14)$. Typically, adult $\mathrm{Hb}$ SS patients show a maximum urinary concentration of about $400 \mathrm{mOsm} / \mathrm{kg}$ (15). It has been suggested that this defect in urinary concentration can be restored to normal in very young children with $\mathrm{Hb} \mathrm{SS}$ submitted to multiple transfusions of $\mathrm{Hb} \mathrm{AA}$ erythrocytes (16). The present data confirm the results described in previous reports showing an early and progressive inability to concentrate urine in $\mathrm{Hb} \mathrm{SS}$ which was also present to a lesser extent in $\mathrm{Hb}$ AS individuals. The generally accepted concept is that the gross destruction of the vasum rectum system impairs tubular function so that the high medullary interstitial solute concentration necessary for urinary concentration cannot be gen-

Table 2 - Laboratory data of patients with sickle cell trait ( $\mathrm{Hb} \mathrm{AS}$ ) and sickle cell anemia ( $\mathrm{Hb} \mathrm{SS}$ ) according to age group.

Values are reported as median (range). RBP $=$ Retinol-binding protein; $\mathrm{ns}=$ not significant. $\mathrm{P}$ values correspond to the comparison between age groups; ${ }^{\mathrm{P}}<0.05 ; \# \mathrm{P}<0.01 ;{ }^{*} \mathrm{P}<0.001 ;{ }^{*} \mathrm{P}<0.0001$ for the comparison with the corresponding Hb AS age group (Mann-Whitney test).

\begin{tabular}{|c|c|c|c|c|c|c|}
\hline \multirow[t]{2}{*}{ Parameter } & \multicolumn{3}{|c|}{$\mathrm{Hb}$ AS } & \multicolumn{3}{|c|}{$\mathrm{Hb} \mathrm{SS}$} \\
\hline & $\leq 15$ years & $>15$ years & $\mathrm{P}$ Value & $\leq 15$ years & $>15$ years & $P$ Value \\
\hline Number of patients & 13 & 27 & & 27 & 39 & \\
\hline Serum creatinine (mg/dl) & $0.60(0.4-0.8)$ & $0.80(0.4-1.1)$ & $<0.002$ & $0.50^{\#}(0.3-0.8)$ & $0.60^{\#}(0.4-1.3)$ & $<0.001$ \\
\hline Creatinine clearance $\left(\mathrm{ml} / \mathrm{min} / 1.73 \mathrm{~m}^{2}\right)$ & $103(97-122)$ & $110(86-212)$ & ns & $114(87-192)$ & $124^{\# \#(111-229)}$ & ns \\
\hline Urinary osmolality (mOsm/kg) & 607 (333-829) & $541(406-772)$ & ns & $419 *(365-580)$ & $393 * *(366-469)$ & $<0.001$ \\
\hline Microalbuminuria (mg/l) & $4.0(0.8-65.4)$ & $6.8(0.8-364.0)$ & ns & $5.40(0.7-12.7)$ & $19.3 * *(1.2-2022)$ & $<0.001$ \\
\hline Hematuria (cells/field, 400X) & $5(0-80)$ & $3(0-10)$ & ns & $2(3-10)$ & $4(1-80)$ & ns \\
\hline Urinary RBP ( $\mu \mathrm{g} / \mathrm{l})$ & $43(5-261)$ & $34(6-124)$ & ns & 37 (7-129) & $64(9-462)$ & $<0.05$ \\
\hline Urinary $ß_{2}$-microglobulin ( $\left.\mu \mathrm{g} / \mathrm{l}\right)$ & $77(12-224)$ & $52(17-206)$ & ns & $60(15-167)$ & $81(15-761)$ & ns \\
\hline Serum ß2-microglobulin (mg/l) & $1.41(0.85-2.20)$ & $1.35(0.58-2.59)$ & ns & $1.65(0.83-2.22)$ & $2.02 *(0.82-3.65)$ & ns \\
\hline
\end{tabular}


erated or maintained (1).

Gross or microscopic hematuria has been detected, usually involving the left kidney, and at times severe enough to endanger the patient's life or be confused with renal malignancy (6). In this study, the percentage of patients with microscopic hematuria was relatively high in both $\mathrm{Hb} \mathrm{SS}$ and $\mathrm{Hb}$ AS groups, being slightly more frequent in the latter (26 and 30\%, respectively). Hematuria was basically of nonglomerular origin, since only in one patient did we find dysmorphic urinary erythrocytes. It has been assumed that hematuria is produced by increased sickling of the erythrocytes in the medulla of the kidney. This causes sludging of the blood in the inner medulla with resulting ischemia and extravasation. At least three factors known to cause sickling could be operative in the medulla of the kidney: increased acidity, hypertonicity and anoxia.

In children with $\mathrm{Hb} \mathrm{SS}$, renal function is characterized by glomerular hyperfiltration and hyperperfusion but, as early as the second decade of life, GFR often declines, despite the persistence of high renal blood flow rates (17). Chronic renal failure has been increasingly diagnosed in $\mathrm{Hb} \mathrm{SS}$ patients and, in some countries, it is one of the most common causes of death among $\mathrm{Hb}$ SS patients over 40 years of age $(2,18)$. In the present study, patients did not have significantly reduced GFR. Glomerular hyperfiltration (GFR $>140 \mathrm{ml} / \mathrm{min}$ ) was more commonly observed in $\mathrm{Hb}$ SS than in $\mathrm{Hb}$ AS individuals.

It has been reported that patients with $\mathrm{Hb}$ SS may present proximal tubule hyperfunction. In fact, increased proximal tubular reabsorption of $\beta_{2}$-microglobulin was found in patients with $\mathrm{Hb} \mathrm{SS}$, resulting in elevated serum levels of the protein. There seems to be a close relationship between clearance of $\beta_{2}$-microglobulin and phosphate clearance, both markers of proximal tubular function $(1,3)$. In addition, other markers of tubular dysfunction may be detected in some pa- tients such as an acidification defect (renal tubular acidosis), hyperuricemia and hyperkalemia $(1,3)$. The great majority of our patients had urinary $\$ 2$-microglobulin and RBP concentrations within the normal range. Only $3 \mathrm{Hb} \mathrm{SS}$ and $2 \mathrm{Hb}$ AS patients had slightly increased urinary excretion of these microproteins, suggesting that significant proximal renal injury is quite uncommon in $\mathrm{Hb} \mathrm{SS}$ and $\mathrm{Hb} \mathrm{AS}$ patients.

We were unable to detect any relationship between $\mathrm{Hb} F$ levels and microalbuminuria. As we have reported earlier, the $\mathrm{Hb} \mathrm{F}$ levels in Brazilian patients with $\mathrm{Hb} \mathrm{SS}$ is relatively low (median $=6.7 \%$, range $=0.7$ 19.2) to protect against severe systemic complications of the disease (19). The higher incidence of the CAR/CAR haplotype in our $\mathrm{Hb}$ SS patients could explain the low level of Hb F observed (20).

We found a high prevalence of microalbuminuria in $\mathrm{Hb}$ SS patients (30\%), mainly in those with a longer duration of disease (49\% in patients older than 15 years). In some of these patients $(\mathrm{N}=8)$ 24-h total proteinuria was also increased. In addition, microalbuminuria was detected in $3 \mathrm{Hb}$ AS individuals. However, no significant correlation was detected between microalbuminuria and GFR. It is noteworthy that although patients in this cohort had preserved renal function (creatinine clearance), microalbuminuria was detected in many of them. Possible mechanisms of microalbuminuria are related to a reduction of ultrafiltration coefficient and loss of glomerular permselectivity. Microalbuminuria seems to be an

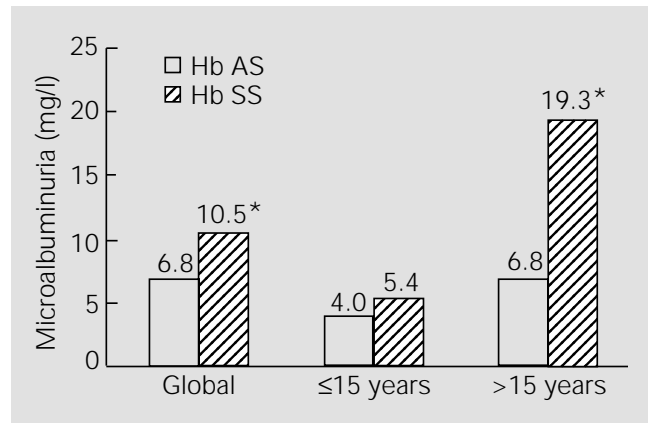

Figure 1 - Microalbuminuria levels in patients with sickle cell trait (Hb AS) and sickle cell anemia (Hb SS) according to age. $* \mathrm{P}<0.01$ for the global comparison between $\mathrm{Hb}$ AS and $\mathrm{Hb} \mathrm{SS}$ groups, and for the comparison between subgroups over 15 years (Hb AS vs Hb SS) (MannWhitney test). 
early indicator of glomerular injury that could precede the development of glomerulosclerosis or other types of glomerulonephritis. In fact, recently, Guasch et al. (17) showed that when albuminuria is present, the ultrafiltration coefficient is already diminished even if GFR is preserved. Therefore, the detection of microalbuminuria seems to be an important marker of glomerular renal injury in patients with $\mathrm{Hb} \mathrm{SS}$.

In conclusion, in this extensive survey of patients with $\mathrm{Hb}$ SS without chronic renal failure we observed that microalbuminuria was frequently detected in $\mathrm{Hb}$ SS patients (half of those older than 15 years), and to a lesser extent in $\mathrm{Hb}$ AS individuals. Microhematuria was another common feature in both groups. Proximal tubular dysfunction was not a relevant finding.

\section{Acknowledgments}

We thank Drs. A.B. Pereira, S.K. Nishida and M.S. Silva for performing renal function studies, and Dr. J. Toporovski for allowing us to study patients at Faculdade de Ciências Médicas da Santa Casa de Misericórdia de São Paulo.

\section{References}

1. Serjeant GR (1992). Sickle Cell Disease. Oxford University Press, Oxford, 261-281.

2. Mapp E, Karasick S, Pollack H, Wechsler RJ \& Karasick D (1987). Uroradiological manifestations of S-hemoglobinopathy. Seminars in Roentgenology, 22: 186-194.

3. de J ong PE, J ong-van den Berg LTW, Sewrajsingh GS, Schouten $H$, Donker AJ M \& Statius van Eps LW (1981). Beta2-microglobulin in sickle cell anemia. Evidence of increased tubular reabsorption. Nephron, 29: 138-141.

4. Falk RJ \& J ennette J C (1994). Renal disease. In: Embury SH, Hebbel RP, Mohandas N \& Steinberg MH (Editors), Sickle Cell Disease. Basic Principles and Clinical Practice. Raven Press, New York, 673-680.

5. Morgan AG \& Serjeant GR (1981). Renal function in patients over 40 with homozygous sickle-cell disease. British Medical J ournal, 282: 1181-1183.

6. Strauss J , Zilleruelo G \& Abitbol C (1986). The kidney and hemoglobin S. Nephron, 43: 241-245.

7. Aoki RY \& Saad STO (1995). Enalapril reduces the albuminuria of patients with sickle cell disease. American J ournal of Medicine, 98: 432-435.

8. Weatherall DJ \& Clegg JB (1981). The
Thalassaemia Syndromes. Blackwell Scientific Publications, Oxford, 744-769.

9. Zago MA, Costa FF \& Bottura C (1982). Teste de solubilidade quantitativo modificado em hemolisados normais e em variantes da hemoglobina. Revista Paulista de Medicina, 100: 15-17.

10. Pembrey ME, MacWadw P \& Weatherall DJ (1972). Reliable routine estimation of small amounts of foetal haemoglobin by alkali denaturation. J ournal of Clinical Pathology, 25: 738-740.

11. Kibrick AC (1958). Extended use of the Kingsley biuret reagent. Clinical Chemistry, 4: 232-241.

12. MacFate RP, Cohn $C$, Eichelberger $L \&$ Cooper J AD (1954). Symposium on azotemia. American J ournal of Clinical Pathology, 24: 511-571.

13. Pereira $A B$, Nishida SK, Vieira J GH, Lombardi MTFC, Silva MS, Ajzen H \& Ramos OL (1993). Monoclonal antibodybased immunoenzymometric assay of retinol-binding protein. Clinical Chemistry, 39: 472-476.

14. Aoki RY \& Saad STO (1990). Microalbuminuria in sickle cell disease. Brazilian J ournal of Medical and Biological Research, 23: 1103-1106.

15. Alleyne GAO, Statius van Eps LW, Addae
SK, Nicholson GD \& Schouten H (1975). The kidney in sickle cell anemia. Kidney International, 7: 371-379.

16. Keitel HG, Thompson D \& Itano HA (1956). Hyposthenuria in sickle cell anemia: a reversible renal defect. J ournal of Clinical Investigation, 39: 998-1007.

17. Guasch A, Cua M \& Mitch WE (1996). Early detection and course of glomerular injury in patients with sickle cell anemia. Kidney International, 49: 786-791.

18. Nissenson AR \& Port FK (1989). Outcome of end-stage renal disease in patients with rare causes of renal failure. I. Inherited and metabolic disorders. Quarterly J ournal of Medicine, 271: 1055-1062.

19. Bordin J O, Kerbauy J, Lourenço DM \& Sesso R (1989). Level of fetal hemoglobin as an indicator of clinical complications in sickle cell anemia. Brazilian J ournal of Medical and Biological Research, 22: 1347-1353.

20. Figueiredo MS, Kerbauy J, Gonçalves MS, Arruda VR, Saad STO, Sonati MF, Stoming T \& Costa FF (1996). Effect of $\alpha$-thalassemia and $ß$-globin gene cluster haplotypes on the hematological and clinical features of sickle-cell anemia in Brazil. American J ournal of Hematology, 53: 7276. 